\title{
Recovery of gastrointestinal swine parasites in anaerobic biodigester systems
}

\author{
Recuperação de parasitas gastrintestinais de suínos em biodigestores anaeróbicos \\ William Alberto Cañon-Franco ${ }^{1 *}$; Ricardo Andrés Henao-Agudelo ${ }^{1}$; José Leandro Pérez-Bedoya ${ }^{1}$ \\ ${ }^{1}$ Departamento de Salud Animal, Facultad de Ciencias Agropecuarias, Universidad de Caldas, Manizales, Caldas, Colombia
}

Received October 31, 2011

Accepted May 23, 2012

\begin{abstract}
Solid and liquid wastes from livestock operations represent important challenges for animal production regarding their impact in the environment and public health. Parasitological tests performed on 80 samples of affluent and effluent waters from three anaerobic biodigestors with flexible structure from swine farms of Caldas - Colombia, showed the presence of Isospora suis (45\%), Eimeria suis (42.5\%), E. espinosa (35\%), Strongyloides ransomi (28.8\%), E. perminuta (12.5\%), E. cerdonis (3.8\%), and E. porci (2.5\%). The additional finding of eggs of Taenia spp. in $10 \%$ of the samples was probably caused by a connection between the human sewage system and the biodigester. Although we observed a mean decrease of $65.6 \%$ of parasites, these levels were insufficient to meet the minimum requirement set by Engelberg's guidelines regarding water quality. This study demonstrates the serious environmental impact that an inadequately treated animal wastewater represents, and has important implications for water resources and human health.
\end{abstract}

Keywords: Wastewater, biodigestor, swine parasites, Taenia, Eimeria.

\section{Resumo}

Resíduos sólidos e líquidos oriundos da suinocultura representam desafios importantes para a produção animal no que diz respeito ao impacto do meio ambiente e em saúde pública. Testes parasitológicos foram realizados em 80 amostras de águas afluentes e efluentes de três biodigestores anaeróbicos com estrutura flexível em granjas de Caldas - Colômbia, demonstrando a presença de Isospora suis (45\%), Eimeria suis (42,5\%), E. espinosa (35\%), Strongyloides ransomi (28,8\%), E. perminuta (12,5\%), E. cerdonis (3,8\%) e E. porci (2,5\%). A constatação adicional de ovos de Taenia spp. em 10\% das amostras foi provavelmente causada pela conexão entre o sistema de esgoto humano e o biodigestor. Embora fosse observada uma diminuição média de 65,6\% dos parasitas, estes níveis são insuficientes para atender ao requisito mínimo estabelecido pelas diretrizes Engelberg em relação à qualidade da água. Este estudo demonstra o grave impacto ambiental que águas residuais animais inadequadamente tratadas representam, bem como as implicações nos recursos hídricos e na saúde humana.

Palavras-chave: Águas residuais, biodigestor, parasitos de suínos, Taenia, Eimeria.

\section{Introduction}

Some countries of the world use the feces of livestock and even humans as an energy source, fertilizer, or incorporated into animal diets (SEMENAS et al., 1999; TOPP et al., 2009), and in the same way there are few regulations around the use of these wastewaters (KUNZ et al., 2009). Anaerobic digesters have been developed as an alternative to solve this problem (CRUZ et al., 2004). Yet, improper handling conditions of these systems and resultant wastewater can cause risks to human and animal health, and to the environment (ANGONESE et al., 2006).

Traditionally, research and health authorities identified Escherichia coli as the main fecal indicator for gauging water quality (EGWARI;

\footnotetext{
*Corresponding author: William Alberto Cañon-Franco

Departamento de Salud Animal, Facultad de Ciencias Agropecuarias,

Universidad de Caldas, Manizales, Caldas, Colombia

e-mail: william.canon@ucaldas.edu.co
}

ABOABA, 2002), but currently other biological variables, such as the presence of helminth eggs, are considered important indicators to establish the quality of different types of wastewater. In fact, the World Health Organization (WHO) suggested the need for epidemiological studies on human health risk associated with this type of farming practice (SALGOT et al., 2006).

Because wastewater generated by the swine industry can contain high parasite loads (VENGLOVSKÝ et al., 2005) and can be reused, previous studies have shown the need to establish limits regarding the presence of viable helminth eggs as a preventive control measure (TOPP et al., 2009). However, more data are needed to strengthen the case for using the proposed parameters as legal requirements in sewage sanitary control (SALGOT et al., 2006). Indeed, pathogen composition found in wastewater can vary widely between farms due to several factors, including the survival 
abilities of the different pathogens, environmental conditions, and characteristics of the livestock production systems (SOBSEY et al., 2006; HÖLZEL; BAUER, 2008).

Our studies present data concerning the retention levels of swine parasites (protozoa and helminths) in wastewater of three biodigester systems in Colombian farms, revealing the degree of environmental contamination by this waste and have important implications regarding the wastewater potential impact.

\section{Materials and Methods}

Were evaluated the parasite burden of flexible structure biodigesters of affluent and effluent wastewater from three swine farms with nursing and finishing production systems. The Colombian farms were located in Santa Rosa de Cabal - Risaralda (farms $A$ and $B$ ) and Palestina - Caldas (farm $C$ ), altitudinal range of 1.050-1.885 m.s.l., temperature and relative humidity of $21{ }^{\circ} \mathrm{C}$ and $85 \%$.

Eighty samples from these farms were collected and assessed fortnightly over six months. After a hydraulic retention period (15 days), four liters of samples were collected at the entrance and exit of the biodigester, in suitable plastic containers. Next, the material was sent to the Laboratory of Veterinary Parasitology of the University of Caldas, Manizales, Colombia.

After previous filtration and overnight sedimentation, about $60 \mathrm{~mL}$ of sediment was centrifuged in $15 \mathrm{~mL}$ conical tubes and the pellet was recovered for parasite observation by the Sheather and McMaster method as previously described (ZARLENGA; TROUT, 2004). Two grams from each sediment sample were fully examined using two slides and two McMaster cameras. Parasite count was performed considering all parasites stages observed in the fields at 40X magnification, and quantified as number of oocysts and eggs per liter of water, following the instructions proposed by the WHO (1983). Using SPSS v.10.0, data were analyzed by the Duncan multiple-range test. Statistical significance was accepted at $\mathrm{P}<0.05$ level.

\section{Results and Discussion}

Of the 80 samples evaluated for parasite burden (40 from affluent and 40 from effluent obtained from biodigesters at swine farms), The samples were subjected to sporulation of oocysts in potassium dichromate solution $(2.5 \%)$ at room temperature until complete observation of sporocysts and sporozoites, and concentrated again by the Sheather and McMaster method and identified on the basis of morphological structures of the sporulated oocysts (SANTOS; LOPES, 1988)

We identified oocysts of Isospora suis (45\%), Eimeria suis (42.5\%), E. espinosa (35\%), E. perminuta (12.5\%), E. cerdonis (3.8\%), E. porci $(2.5 \%)$, as well as eggs of Strongyloides ransomi (28.8\%) and Taenia spp. (10\%). Farm B showed a greater number of positive samples for E. espinosa and E. suis. Eggs of Taenia spp. were present only in farm $C$, while eggs of $S$. ransomi were predominant in farms $A$ and $B$ (Table 1 ).

The wide range of gastrointestinal parasites found by our study is in agreement with data obtained by other studies from both effluent and biosolids in swine feces (CABALLEROHERNÁNDEZ et al., 2004; BORNAY-LLINARES et al., 2006). Our results constitute the first report of the presence of different species of Eimeria of swine in Colombia, identified through the use of affluent and effluent wastewater, a genus of relatively high importance in pig farming because this parasite is responsible for neonatal diarrhea and poor performance in pigs during the fattening period and therefore for livestock economic losses (KOUDELA; VÍTOVEC, 1998).

Diarrhea in pigs during the breeding and nursing phases is usually associated with Isospora suis infection (WORLICZEK et al., 2009). Although farm $A$ presented a smaller number, effluent water from all farms contained sporulated oocysts of $I$. suis, indicating environmental contamination by infective forms. Likewise, other potential opportunistic pathogens such as E. perminuta, E. porci, E. cerdonis, and E. espinosa were present in samples (SOLAYMANIMOHAMMADI; PETRI JUNIOR, 2006).

The methods used in this study allowed easy retrieval of helminth eggs. Similar results were obtained for Taenia saginata by zinc sulfate solution technique (BARBIER et al., 1990). The recovery of tapeworms such as Hymenolepis diminuta in anaerobic systems under these conditions suggests that their viability was enhanced. In this study, the finding of eggs Taenia spp. in the sewage of swine farms suggesting an increased risk of infection and the likelihood of taeniasis in workers or residents near the pig farm, was caused by a connection of the human sewage system to the biodigesters in farm $C$. Moreover, the result indicates the unfitness of this water for recreational, agricultural, and human

Table 1. Number (N) of positive samples and recovered (\%) of parasite forms (oocysts and eggs) by Sheather technique in affluent and effluent wastewaters samples collected from flexible structure digesters from three swine farms in Colombia $(\mathrm{N}=80)$.

\begin{tabular}{|c|c|c|c|c|c|}
\hline \multirow[t]{2}{*}{ Parasite } & \multicolumn{3}{|c|}{ Number of positive samples } & \multirow[t]{2}{*}{ Recovery N (\%) } & \multirow[t]{2}{*}{$\mathbf{P}$} \\
\hline & Farm $A$ & Farm $B$ & Farm $C$ & & \\
\hline Eimeria cerdonis & 0 & 3 & 0 & $3(3.8 \%)$ & 0.0290 \\
\hline Eimeria espinosa & 8 & 17 & 3 & $28(35 \%)$ & $<0.0001$ \\
\hline Eimeria perminuta & 2 & 8 & 0 & $10(12.5 \%)$ & $<0.0001$ \\
\hline Eimeria porci & 0 & 2 & 0 & $2(2.5 \%)$ & 0.0692 \\
\hline Eimeria suis & 6 & 20 & 8 & $34(42.5 \%)$ & $<0.0001$ \\
\hline Isospora suis & 5 & 11 & 20 & $36(45 \%)$ & $<0.0001$ \\
\hline Strongyloides ransomi & 10 & 10 & 3 & $23(28.8 \%)$ & 0.0440 \\
\hline Taenia spp. & 0 & 0 & 8 & $8(10 \%)$ & $<0.0001$ \\
\hline
\end{tabular}

*Significance $\mathrm{P}<0.05$ Duncan's test. 
use. Indeed, presence of Taenia spp. in these wastewaters may cause serious impact on public health (CLIVER, 2009).

Temperature is a determining factor for the biodigester systems in terms of biogas production, metabolism of substrates, and $\mathrm{pH}$ reduction, which are variables directly related with hydraulic retention time system (CASTILLO et al., 2006) and thus with the level of survival of biological organisms in the effluent. In this context, L3 larvae of Haemonchus spp., Cooperia spp., and Oesophagostomum spp. may survive for 35 to 40 days in effluents (AMARAL et al., 2004; MENTZ et al., 2004) and eggs of Ascaris spp., Toxocara spp., Truchuris spp., and Hymenolepis spp. remain viable for longer periods under laboratory conditions (O'DONNELL et al., 1984). Recovery of viable and pathogenic parasites was shown herein to be higher than that reported by others, probably because were conducted this study for a long period of six months, a longer time span than that employed previously. This result is in agreement with that reported for eggs Toxocara canis and Ascaris suum in anaerobic systems (PAPAJOVÁ et al., 2008).

Overall, was demonstrated that total parasite removal (protozoa and helminths) was inadequate in the three farms analyzed: $65.6 \%$, $86.2 \%$, and $10.6 \%$ for farms $A, B$, and $C$, respectively. The removal rates observed were lower than those reported by other studies ranging from $86.7 \%$ to $99.9 \%$ (REINOSO; BECARES, 2008) and from $78.6 \%$ to $100 \%$ (NÚNEZ et al., 1987). Elimination of Strongyloides ransomi was found to be more efficient (e.g., farm $A$ registered a level of $76.9 \%$, see Figure 1) and may be due to the treatment system employed, that is, biodigesters with flexible structure. This finding is in accordance with the data published by Cruz et al. (2004) and suggests that this system is more effective than primary systems for this worm. The parasite burden is affected
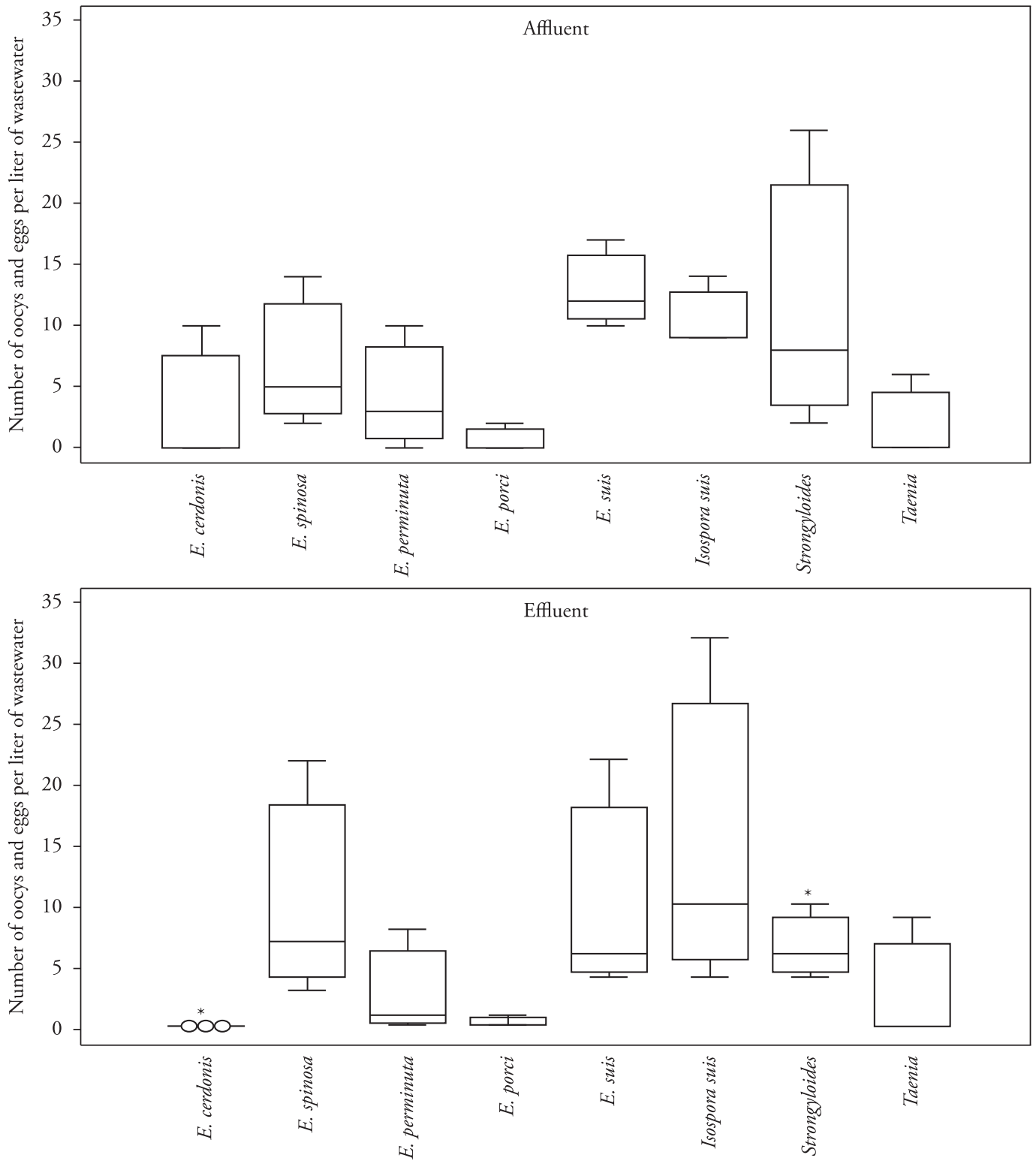

Figure 1. Average parasites (oocysts and eggs)/liter of water samples from affluent and effluent obtained from continuous flow digesters from three pig farms in Colombia (McMaster technique). *Significance $\mathrm{P}<0.05$ Duncan's test. 
at temperatures of $35^{\circ} \mathrm{C}$, which completely eliminate protozoan oocysts and reduce helminth eggs (78.6\%) (NÚNEZ et al., 1987). Other factors such as ammonia concentration and anaerobic characteristics of the system may be accounted (HANSEN et al., 1999). Indeed, the operating conditions of the digesters, as well as their capacity, temperature, and $\mathrm{pH}$, have a great effect on the decline and survival of the pathogen load (NÚNEZ et al., 1987; HANSEN et al., 1999; SOBSEY et al., 2006; CHAE et al., 2008). In this work showed that the reduction of parasitic load of the farms was significantly inefficient; the conditions above mentioned for swine farming can leave parasitic residual loads in the water. Those contaminated water sources pose a risk to public health, since are used for other purposes in these farms.

The hydraulic retention time of 15 days employed in our study was lower than that reported in Brazil by Amaral et al. (2004). In both studies, survival of parasites was evident, indicating that retention periods between 15 and 20 days do not reduce worm viability, and suggest the need for periods longer than 30 days to inactivate $80 \%$ of the eggs (FURLONG; PADILHA, 1996). Indeed, even under laboratory conditions, periods of at least 45 days were shown to be necessary for an optimal removal of coccidia oocysts and eggs of Ascaris spp. (NÚNEZ et al., 1987).

According to Engelberg's guidelines, one parameter to assess whether treated water is within acceptable quality conditions is the finding of less than one viable intestinal nematode egg per liter of water (STRAUSS, 1985; SALGOT et al., 2006). In the light of this guideline, the minimum and maximum values of helminth eggs in the samples analyzed in this study, 2 to 26 eggs/liter respectively revealed that the water is inappropriate for residential, agricultural, aquaculture, and industrial use because it surpassed the minimum values allowed for helminth eggs.

\section{Conclusions}

The investigations on affluent and effluent wastewater from three pig farms and found a significantly poor elimination of parasite loads. Our data have important implications due a potential environmental and public health impact generated by the c swine farming practices urrently employed regarding wastewater management. Indeed, none of the samples demonstrated a minimum requirement according Engelberg's guidelines, and were therefore considered unfit for agricultural use or human consumption.

\section{References}

Amaral CMC, Amaral LA, Lucas Júnior J, Nascimento AA, Ferreira DS, Machado MRF. Biodigestão anaeróbia de dejetos de bovinos leiteiros submetidos a diferentes tempos de retenção hidráulica. Ciênc Rural 2004; 34(6): 1897-1902. http://dx.doi.org/10.1590/S010384782004000600035

Angonese AR, Campos AT, Zacarkim CE, Matsuo MS, Cunha F. Eficiência energética de sistema de produção de suínos com tratamento dos resíduos em biodigestor. Rev Bras Eng Agric Ambient 2006; 10(3): 745-750.

Barbier D, Perrine D, Duhamel C, Doublet R, Georges P. Parasitic hazard with sewage sludge applied to land. Appl Environ Microbiol 1990; 56(5): 1420-1422.
Bornay-Llinares FJ, Navarro-I-Martínez L, García-Orenes F, Araez $\mathrm{H}$, Pérez-Murcia MD, Moral R. Detection of intestinal parasites in pig slurry: A preliminary study from five farms in Spain. Livest Sci 2006; 102(3): 237-242. http://dx.doi.org/10.1016/j.livsci.2006.03.023

Caballero-Hernández AI, Castrejón-Pineda F, Martínez-Gamba R, Angeles-Campos S, Pérez-Rojas M, Buntinx SE. Survival and viability of Ascaris suum and Oesophagostomum dentatum in ensiled swine faeces. Bioresour Technol 2004; 94(2): 137-142. http://dx.doi.org/10.1016/j. biortech.2003.12.008

Castillo MEF, Cristancho DE, Arellano AV. Study of operational conditions for anaerobic digestion of urban solid wastes. Waste Manag 2006; 26(5): 546-556. http://dx.doi.org/10.1016/j. biortech.2006.11.063

Chae KJ, Jang A, Yim SK, Kim IS. The effects of digestion temperature and temperature shock on the biogas yields from the mesophilic anaerobic digestion of swine manure. Bioresour Technol 2008; 99(1): 1-6. http:// dx.doi.org/10.1016/j.biortech.2006.11.063

Cliver DO. Disinfection of animal manures, food safety and policy. Bioresour Technol 2009; 100(22): 5392-5394. http://dx.doi. org/10.1016/j.biortech.2009.04.038

Cruz E, Martínez V, Naranjo R, Sosa R. Evaluación microbiológica del efluente anaerobio de un biodigestor de cúpula fija. Rev Computad Prod Porcina 2004; 11(2):89-95.

Egwari L, Aboaba OO. Environmental impact on the bacteriological quality of domestic water supplies in Lagos, Nigeria. Rev Saúde Pública 2002; 36(4): 513-520. http://dx.doi.org/10.1590/S003489102002000400019

Furlong J, Padilha T. Viabilidade de ovos de nematódeos gastrintestinais de bovinos após passagem em biodigestor anaeróbio. Ciênc Rural 1996; 26(2): 269-271. http://dx.doi.org/10.1590/S010384781996000200017

Hansen KH, Angelidaki I, Ahring BK. Improving thermophilic anaerobic digestion of swine manure. Wat Res 1999; 33(8): 1805-1810. http:// dx.doi.org/10.1016/S0043-1354(98)00410-2

Hölzel C, Bauer J. Salmonella spp. in Bavarian liquid pig manure: occurrence and relevance for the distribution of antibiotic resistance. Zoonoses Public Health 2008; 55(3): 133-138. http://dx.doi.org/10.1111/ j.1863-2378.2007.01102.x

Koudela B, Vítovec J. Biology and pathogenicity of Eimeria neodebliecki Vetterling, 1965 in experimentally infected pigs. Parasitol Int 1998; 47(4): 249-256. http://dx.doi.org/10.1016/S13835769(98)00030-0

Kunz A, Miele M, Steinmetz RLR. Advanced swine manure treatment and utilization in Brazil. Bioresour Technol 2009; 100(22): 5485-5489. http://dx.doi.org/10.1016/j.biortech.2008.10.039

Mentz MB, Wiest JM, Gonçalves PC. Viability of bovine's Strongyloidea eggs in a system of anaerobic biodigestion. Parasitol Latinoam 2004; 59(3-4): 148-152.

Núñez SF, Urrutia SF, Urcelay VS, Oviedo H.P. Microbiological and parasitological study in swine manure treated by anaerobic biodigestion. Av Cs Vet 1987; 2(1): 37-41.

O’Donnell CJ, Meyer KB, Jones JV, Benton T, Kaneshiro ES, Nichols JS, et al. Survival of parasite eggs upon storage in sludge. Appl Environ Microbiol 1984; 48(3): 618-625. 
Papajová I, Juriš P, Szabová E, Venglovský J, Sasáková N, Sěfčíková $\mathrm{H}$, et al. Decontamination by anaerobic stabilization of the environment contaminated with enteronematode eggs Toxocara canis and Ascaris suum. Bioresour Technol 2008; 99(11): 4966-4971. http://dx.doi.org/10.1016/j. biortech.2007.09.044

Reinoso R, Becares E. The occurrence of intestinal parasites in swine slurry and their removal in activated sludge plants. Bioresour Technol 2008; 99(14): 6661-6665. http://dx.doi.org/10.1016/j. biortech.2007.11.056

Salgot M, Huertas E, Weber S, Dott W, Hollender J. Wastewater reuse and risk: definition of key objectives. Desalination 2006; 187(1-3): 29-40. http://dx.doi.org/10.1016/j.desal.2005.04.065

Santos NM, Lopes CWG. Morfologia dos oocistos das espécies da família Eimeriidae Minchin, 1903 (Protozoa: Apicomplexa) Parasitos de Suínos. Arq Fluminense Med Vet 1988; 3(2): 41-44.

Semenas L, Brugni N, Viozzi G, Kreiter A. Control of parasites in domestic sewage. Rev Saúde Pública 1999; 33(4): 379-384. http://dx.doi. org/10.1590/S0034-89101999000400009

Sobsey MD, Khatib LA, Hill VR, Alocilja E, Pillai S. Pathogens in animal wastes and the impacts of waste management practices on their survival, transport and fate. In: Rice JM, Caldwell DF, Humenik FJ. Animal Agriculture and the Environment. St. Joseph: ASABE; 2006. p. 609-666.
Solaymani-MohammadiS, PetriJuniorWA.Zoonoticimplications of the swinetransmitted protozoal infections. Vet Parasitol 2006; 140(3-4): 189-203. http://dx.doi.org/10.1016/j.vetpar.2006.05.012

Strauss M. Health aspects of nightsoil and sludge use in agriculture and aquaculture - Health aspects of wastewater and excreta use in agriculture and aquaculture: The Engelberg report. IRCWD News 1985; 23: 11-17.

Topp E, Scott A, Lapen DR, Lyautey E, Duriez P. Livestock waste treatment systems for reducing environmental exposure to hazardous enteric pathogens: Some considerations. Bioresour Technol 2009; 100(22): 5395-5398. http:// dx.doi.org/10.1016/j.biortech.2008.11.001

Venglovský J, Martinez J, Plachá I. Hygienic and ecological aspects associated with the utilization of biosolids and excrement in agriculture. Folia Vet 2005; 49(3): 21-24.

World Health Organization - WHO. WHO/Guidelines on studies in environmental health, 27. Ginebra: WHO; 1983. Available from: http:// www.inchem.org/documents/ehc/ehc/ehc27.htm.

Worliczek HL, Mundt HC, Ruttkowski B, Joachim A. Age, not infection dose, determines the outcome of Isospora suis infections in suckling piglets. Parasitol Res 2009; 105(S1): 157-162. http://dx.doi.org/10.1007/ s00436-009-1507-9

Zarlenga DS, Trout JM. Concentrating, purifying and detecting waterborne parasites. Vet Parasitol 2004; 126(1-2): 195-217. http:// dx.doi.org/10.1016/j.vetpar.2004.09.001 